\title{
PENERAPAN MODEL KONSTRUKTIVISTIK DENGAN MEDIA FILE GAMBAR 3D UNTUK MENINGKATKAN MOTIVASI DAN PRESTASI HASIL BELAJAR
}

\author{
Marsudi \\ SMK Negeri 2 Pengasih \\ Email: mars_udi34@yahoo.com
}

\begin{abstract}
The objective of this study was to improve the students' motivation and achievement in the subject of Budget Plan through the implementation of the constructivist learning model with three-dimensional image media at the Department of Wood Construction Engineering of SMK Negeri 2 Pengasih. This study was a classroom action research conducted in two cycles. The subjects of this study were 28 students of class III of Wood Construction Engineering, SMK Negeri 2 Pengasih in the second semester of the academic year of 2014/ 2015. The data of the student's motivation was obtained using questionnaires adapted from the model of John Keller, namely; Action, Relevance, Confidence and Satisfaction (ARCS). While the data of the students' achievement was obtained using tests. The results revealed the application of the constructivist learning model increases the students' motivation and achievement. It's indicated by the improvement of the students' motivation from the first cycle to the second cycle that was $28.52 \%$. While the improvement of the students' achievement, learning absorption and mastery were $7.34 \%, 7.34 \%$, and $75.01 \%$ respectively.
\end{abstract}

Keywords: achievement, constructivist model, learning motivation

\begin{abstract}
ABSTRAK
Penelitian ini bertujuan untuk meningkatkan motivasi dan prestasi hasil belajar siswa pada pembelajaran Rencana Anggaran Biaya (RAB) melalui model konstruktivistik dengan media file gambar 3 dimensi pada siswa kelas III Teknik Konstruksi Kayu SMK Negeri 2 Pengasih. Penelitian ini adalah Penelitian Tindakan Kelas yang dilaksanakan dalam dua siklus. Subyek penelitian adalah siswa kelas III Teknik Konstruksi Kayu SMK Negeri 2 Pengasih semester genap tahun pelajaran 2014/ 2015 yang berjumlah 28 siswa. Data tentang motivasi siswa diperoleh dengan metode angket model dari John Keller yaitu; Action, Relevance, Confidence, dan Satisfaction (ARCS), sedangkan prestasi hasil belajar diperoleh dengan metode tes. Hasil penelitian menunjukkan bahwa penerapan model konstrukrivistik dapat meningkatkan motivasi dan prestasi belajar siswa. Peningkatan motivasi belajar siswa dari siklus I ke siklus II sebesar $28,52 \%$. Sedangkan pada aspek lain dari siklus I ke siklus II yaitu terdapat peningkatan prestasi hasil belajar rata-rata skor 7,34\%, daya serap 7,34\%, dan ketuntasan belajar $75,01 \%$.
\end{abstract}

Kata kunci: model konstruktivistik, motivasi belajar, prestasi hasil belajar

\section{PENDAHULUAN}

Problem pendidikan selalu ada beriringan dengan perkembangan dan peningkatan kemampuan siswa, situasi dan kondisi lingkungan, perkembangan ilmu pengetahuan teknologi dan informasi dan budaya yang sangat pesat dewasa ini sehingga secara langsung maupun tidak langsung berdampak terhadap siswa (Zainal, 2006: 130). Saat ini pelaksanaan pembelajaran dengan pendekatan konvensional masih sering dilakukan oleh sebagian guru di SMK Negeri 2 Pengasih dan ternyata hasilnya kurang efektif lagi karena menimbulkan rasa kejenuhan yang dialami oleh siswa dalam mengikuti pembelajaran. Siswa cenderung kurang aktif karena taraf motivasi belajar masih rendah sehingga berpengaruh terhadap prestasi hasil belajar yang kurang optimal. Hal ini yang mendasari pelaksanaan Penelitian Tindakan Kelas (PTK) dengan harapan penelitian ini dapat mengembangkan strategi pembelajaran yang paling efisien dan efektif sehingga dapat menumbuhkan dan 
meningkatkan motivasi belajar siswa agar dapat meraih prestasi hasil belajar yang optimal. Selaras dengan pendapat yang dikemukakan oleh Endang (2011: 60), bahwa PTK bertujuan untuk mengembangkan strategi pembelajaran yang paling efisien dan efektif pada situasi alamiah.

Dengan demikian guru dituntut selalu meningkatkan diri terhadap berbagai hal yang berkaitan dengan tugas dan kewajibannya sehingga guru lebih inovatif, kreatif, proaktif serta profesional dalam melaksanakan kegiatan pembelajaran dalam rangka mengantarkan kesuksesan para siswa. Bertitik tolak dari latar belakang masalah yang telah diuraikan di muka maka penulis merumuskan beberapa permasalahan sebagai berikut: (1) Apakah penerapan model konstruktivistik dengan media file gambar 3 dimensi dapat meningkatkan motivasi dalam pembelajaran Rencana Anggaran Biaya pada siswa kelas III TKKY SMK Negeri 2 Pengasih Tahun 2014/2015; (2) Apakah penerapan model konstruktivistik dengan media file gambar 3 dimensi dapat meningkatkan prestasi hasil pembelajaran Rencana Anggaran Biaya pada siswa kelas III TKKY SMK Negeri 2 Pengasih Tahun 2014/2015. Berdasarkan rumusan masalah tersebut maka pemecahan masalah yang ditempuh dalam penelitian ini adalah penerapan model konstruktivistik dengan file gambar 3 dimensi dalam pembelajaran Rencana Anggaran Biaya pada siswa kelas III TKKY SMK Negeri 2 Pengasih Tahun 2014/2015.

Dengan menerapkan model dan media pembelajaran tersebut diharapkan dapat meningkatkan taraf motivasi belajar siswa dan meningkatkan prestasi hasil belajar siswa. Mengacu pada pokok permasalahan di atas, maka tujuan penelitian ini adalah sebagai berikut: (1) Mengetahui taraf peningkatan motivasi belajar siswa setelah diterapkannya model konstruktivistik dengan media file gambar 3 dimensi pembelajaran rencana anggaran biaya pada siswa kelas III TKKY SMK Negeri 2 Pengasih tahun 2014/2015;
(2) Mengetahui taraf peningkatan prestasi hasil belajar siswa setelah diterapkannya model konstruktivistik dengan media file gambar 3 dimensi pembelajaran rencana anggaran biaya pada siswa kelas III TKKY SMK Negeri 2 Pengasih tahun 2014/2015. Manfaat hasil penelitian yang diharapkan adalah (1) Bagi siswa; (a) memiliki perspektif yang lebih jelas dan terarah tentang pembelajaran Rencana Anggaran Biaya Konstruksi secara efektif, (b) lebih mudah mengidentifikasi problem yang timbul dalam kegiatan pembelajaran sehingga mudah untuk menentukan solusi pemecahannya, (c) pencapaian penguasaan kompetensi materi pembelajaran oleh siswa lebih efektif. (2) Bagi guru; (a) perencanaan program peningkatan efektifitas pembelajaran Rencana Anggaran Biaya Konstruksi di masa yang akan datang, (b) evaluasi diri dalam melaksanakan tugas kegiatan belajar dan mengajar, (c) mengetahui kelebihan dan kekurangan dalam melaksanakan kegiatan pembelajaran, bila terdapat kekurangan maka hasil Penelitian Tindakan Kelas (PTK) ini dapat dipakai sebagai salah satu solusi untuk memperbaikinya.

Berdasarkan undang-undang Nomor 20 tahun 2003 tentang Sistem Pendidikan Nasional pembelajaran adalah proses interaksi peserta didik dengan pendidik dan sumber belajar pada suatu lingkungan belajar. Pusat Bahasa Depdiknas (1996: 14) menjelaskan bahwa pembelajaran adalah proses, cara, menjadikan orang atau makhluk hidup belajar, sedangkan belajar adalah berusaha memperoleh kepandaian atau ilmu, berubah tingkah laku atau tanggapan yang disebabkan oleh pengalaman. Soetomo (1993: 68) menjelaskan belajar adalah proses pengelolaan lingkungan oleh seseorang dengan sengaja dilakukan sehingga memungkinkan untuk belajar melakukan atau mempertunjukan tingkah laku tertentu. Berdasarkan uraian di atas maka belajar merupakan proses yang disengaja yang menyebabkan peserta didik atau siswa belajar pada suatu lingkungan siswa untuk melakukan kegiatan pada situasi tertentu. 
Model pembelajaran merupakan istilah yang digunakan untuk menggambarkan suatu penyelenggaraan proses belajar mengajar dari awal sampai akhir (Endang, 2011). Model pembelajaran digunakan sebagai pedoman bagi guru dalam merencanakan dan melaksanakan kegiatan belajar dan mengajar berisi unsurunsur antara lain; tujuan dan asumsi, tahapan kegiatan, setting pembelajaran, kegiatan guru dan siswa, perangkat pembelajaran dan dampak hasil belajar.

Model konstruktivistik atau constructivist theories of learning adalah pembelajaran yang mengutamakan peserta didik secara aktif, membangun pembelajaran peserta didik sendiri secara mandiri dan menstransfer informasi yang kompleks. Mengacu pada pemikiran Aronson et al (1978) bahwa pada proses pembelajaran guru memberi kesempatan kepada peserta didik dalam proses belajar dan sosialisasi yang berkesinambungan dan berorientasi pada model pembelajaran konstruktivistik kooperatif jigsaw.

Degeng (2001) memaparkan terdapat komparasi mendasar antara pembelajaran model behavioristik dan konstruktivistik. Belajar menurut behavioristik merupakan perolehan pengetahuan, sedangkan mengajar adalah meningkatkan pengetahuan kepada pembelajar atau peserta didik. Sedangkan belajar menurut konstruktivistik yaitu penyusunan pengetahuan dari pengalaman konkrit, aktivitas kolaboratif dan refleksi serta interaksi, sedangkan mengajar adalah menata situasi dan lingkungan agar pembelajar atau peserta didik termotivasi dalam menggali makna dan menghargai ketidakpastian.

Model pembelajaran konstruktivistik terdiri atas empat tahapan atau sintak yang meliputi: (1) Apersepsi merupakan kegiatan menghubungkan konsepsi awal, mengungkapkan pertanyaan-pertanyaan dari materi sebelumnya yang merupakan konsep prasyarat; (2) Eksplorasi yaitu tahap ketika peserta didik mengungkapkan dugaan sementara terhadap konsep yang akan dipelajari. Kemudian peserta didik menggali, menyelidiki, dan menemukan sendiri konsep sebagai jawaban dari dugaan sementara yang dikemukakan pada tahapan sebelumnya. (3) Diskusi dan penjelasan konsep adalah tahap saat peserta didik mengkomunikasikan hasil penyelidikan dan temuan, pada tahap ini pula guru menjadi fasilitator dalam menampung dan membantu peserta didik membuat kesepakatan kelas; (4) Pengembangan dan aplikasi adalah tahap guru memberikan penekanan terhadap konsep-konsep esensial, kemudian peserta didik membuat kesimpulan melalui bimbingan guru dan menerapkan pemahaman konseptual yang telah diperoleh melalui pembelajaran saat itu melalui pengerjaan tugas.

Media merupakan bagian yang penting karena dengan media dapat memperlancar dan mempercepat tercapainya tujuan pembelajaran. Kata media merupakan bentuk jamak dari medium yang artinya tengah. Dalam bahasa Indonesia kata medium diartikan sebagai antara atau sedang (John, 1988: 14). Media pembelajaran adalah semua alat bantu atau benda yang digunakan untuk kegiatan untuk kegiatan belajar mengajar, dengan maksud menyampaikan pesan (informasi) pembelajaran dari sumber (guru maupun sumber lain) kepada penerima (dalam hal ini siswa atau warga belajar). Dari pengertian di atas maka fungsi media pembelajaran besar terhadap kesuksesan pembelajaran. Akhmad (2008) mengemukakan bahwa fungsi media adalah: (1) media dapat mengatasi keterbatasan pengalaman yang dimiliki oleh para siswa, (2) media dapat melampaui batasan ruang kelas, (3) media memungkinkan interaksi langsung antara siswa dengan lingkungan, (4) media menghasilkan keseragaman pengamatan, (5) media dapat menanamkan konsep dasar yang benar, kongkrit, dan realistis, (6) media membangkitkan motivasi dan merangsang anak untuk belajar, (7) media memberikan pengalaman menyeluruh tentang hal kongkrit sampai yang abstrak. Media pembelajaran adalah segala sesuatu yang dapat digunakan untuk menyalurkan pesan dari pengirim ke penerima pesan (Arief dkk, 2008: 7). Dalam kegiatan pembelajaran berarti media pembelajaran merupan alat untuk merangsang pikiran, perasaan, perhatian, dan minat serta 
perhatian siswa sehingga proses belajar mengajar dapat terbangun dan terjalin dengan harmonis. Schramm (1977) menjelaskan media pembelajaran adalah teknologi pembawa pesan yang dapat dimanfaatkan untuk keperluan pembelajaran. Maka dapat diambil simpulan dari beberapa pendapat para ahli tersebut bahwa media pembelajaran merupakan alat bantu pembelajaran dalam rangka menyampaikan materi sebagai pesan agar lebih mudah diterima oleh penerima pesan dalam hal ini adalah siswa, terlebih siswa lebih termotivasi serta aktif dalam mengikuti pembelajaran.

Menurut beberapa literatur, File System atau Sistem Berkas merupakan metode penyimpanan file pada komputer atau media penyimpanan komputer dalam mengatur lokasi file tersebut. Ada juga yang menyebut bahwa File System adalah struktur logika yang digunakan untuk mengendalikan akses terhadap data yang ada pada disk (Dhani, 2014). File System memiliki dua bagian: (1) kumpulan file yang masing-masing menyimpan data-data yang berhubungan, (2) struktur direktori yang mengorganisasi dan menyediakan informasi mengenai seluruh file dalam sistem.

Fungsi File System diantaranya untuk memberi nama pada berkas dan meletakkannya pada media penyimpanan. Berdasar uraian tentang file system di atas dapat dianalogkan file gambar yang dimaksud dalam tulisan ini adalah file yang digunakan untuk menyimpan data gambar obyek gambar bangunan gedung sederhana yang dipakai sebagai media pembelajaran. Di dalam file system gambar 3 dimensi ini telah diatur layer-layer untuk menggambar satu komponen obyek (contoh layer komponen lantai, layer komponen dinding, layer komponen pintu dan jendela, layer komponen atap) dan seterusnya. Layer ini dapat diaktifkan (on) dan dapat dinonaktifkan (off). Komponen yang diamati dapat di-on-kan agar lebih fokus dan jelas, sedangkan komponen yang lain dapat di-off-kan dahulu agar tidak mengecoh pengamatan.

Syaiful (2002: 114) memaparkan bahwa motivasi adalah suatu pendorong yang mengubah energi dalam diri seseorang ke dalam bentuk aktivitas nyata untuk mencapai tujuan tertentu. Uzer (2000: 28) mendefinisikan motivasi sebagai suatu proses untuk menggiatkan motif-motif menjadi perbuatan atau tingkah laku untuk memenuhi kebutuhan dan mencapai tujuan, atau keadaan dan kesiapan dalam diri individu yang mendorong tingkah laku untuk berbuat sesuatu dalam mencapai tujuan tertentu. Motivasi sangat diperlukan dalam pelaksanaan proses belajar karena seseorang yang tidak memiliki motivasi tidak akan melakukan kegiatan termasuk dalam belajar. Hal ini senada dengan pendapat yang diungkapkan oleh Mohammad (2001: 3) bahwa siswa yang termotivasi dalam sesuatu akan menggunakan proses kognitif yang lebih tinggi dalam mempelajari materi itu, sehingga siswa itu akan menyerap dan mengendapkan materi itu dengan lebih baik.

Menurut jenisnya, motivasi dibagi atas dua macam yaitu motivasi intrinsik dan ekstrinsik. (1) Motivasi Intrinsik menurut Syaiful (2002: 115) adalah motif-motif yang menjadi aktif atau berfungsinya tidak perlu dirangsang dari luar, karena dalam setiap diri individu sudah ada dorongan untuk melakukan sesuatu. Sedangkan menurut pendapat Uzer (2000: 29) jenis motivasi ini timbul sebagai akibat dari dalam individu, apakah karena ada ajakan, suruhan, atau paksaan dari orang lain sehingga dengan kondisi yang demikian akhirnya mau melakukan sesuatu atau belajar. (2) Motivasi Ekstrinsik adalah motif-motif yang aktif dan berfungsi karena ada perangsang dari luar (Syaiful, 2002: 117). Pendapat lain mengemukakan bahwa jenis motivasi ekstrinsik ini timbul akibat pengaruh dari luar individu, apakah karena ada ajakan, suruhan, atau paksaan dari orang lain sehingga dengan kondisi yang demikian akhirnya melakukan seuatu atau belajar. Misalnya seseorang yang mau belajar karena disuruh oleh orang tua agar mendapat peringkat pertama di kelas (Uzer, 2000: 29).

Untuk mengukur taraf motivasi belajar siswa dapat mengadopsi perangkat pengukur 
motivasi yang disusun oleh Keller (1983) yang dapat diterapkan dalam proses pembelajaran, perangkat tersebut dikenal dengan model ARCS untuk mengukur empat macam kondisi motivasional yaitu: (1) Attention (perhatian), (2) Relevance (relevansi), (3) Confidence (percaya diri), dan (4) Satisfaction (kepuasan).

Prestasi belajar adalah hasil belajar yang dinyatakan dalam bentuk nilai atau dalam bentuk skor, setelah siswa mengikuti pelajaran (Daryanto, 2011: 160). Sedangkan Tukiran, dkk menjelaskan (2011: 69) bahwa yang dimaksud dengan pretasi belajar yaitu berkenaan dengan hasil tes yang mencerminkan kemampuan siswa dalam menguasai materi pelajaran. Prestasi belajar seseorang atau siswa ini akan mempengaruhi pada taraf hasil belajar yang mencakup aspek-aspek yang berkenaan dengan perubahan dan kemampuan yang telah dimiliki oleh siswa pada ranah cognitive (pengetahuan), affective (sikap), dan juga psichomotoric (keterampilan), perubahan yang dimiliki oleh siswa tersebut dapat berupa kreativitas, komunikasi, interaksi dan lain sebagainya.

Dengan demikian berdasarkan beberapa pendapat yang telah diuraikan di atas dapat diambil kesimpulan bahwa prestasi belajar Rencana Anggaran Biaya (RAB) Konstruksi adalah merupakan hasil evaluasi atau tes yang mencerminkan tentang kemampuan siswa dalam menguasai materi mata pelajaran tersebut baik yang mencakup ranah pengetahuan, sikap, dan keterampilan. Anggaran biaya dari suatu bangunan merupakan harga dari bangunan itu sendiri (Muhammad dan Suratman, 1979: 9). RAB Konstruksi merupakan salah satu mata pelajaran produktif dalam struktur kurikulum 2006 Kompetensi Keahlian Teknik Konsruksi Kayu, Program Keahlian Teknik Bangunan yang terdiri atas tiga kajian pokok dengan 1 (satu) Standar Kompetensi (SK): menyusun Rencana Anggaran Biaya (RAB) Konstruksi dan terdiri dari 3 (tiga) Kompetensi Dasar (KD) yaitu: (1) mengidentifikasi jenis bahan konstruksi, pokok pembahasan ini adalah mengidentifikasi jenis dan macam bahan yang digunakan dalam suatu konstruksi bangunan (bangunan gedung, bangunan air, bangunan jalan dan jembatan); (2) melakukan analisa satuan harga bahan dan upah kerja untuk pembuatan bangunan meliputi; bangunan gedung, bangunan air, bangunan jalan dan jembatan; (3) menghitung harga keseluruhan dari suatu bangunan, baik bangunan gedung, bangunan air, maupun bangunan jalan dan jembatan.

Di bawah ini terdapat beberapa hal penting terkait dengan mata pelajaran Menyusun RAB Konstruksi Teknik Bangunan, antara lain; (a) Fungsi: untuk mengembangkan pengetahuan, keterampilan, dan sikap pada peserta didik karena pelajaran tersebut sangat berguna ketika bermasyarakat terlebih dalam dunia usaha dan dunia industri yang berkecimpung pada jasa konsultan dan konstruksi, (b) Tujuan: membekali peserta didik agar mampu mengembangkan pengetahuan, keterampilan dan sikap yang berguna bagi dirinya. Bangunan fisik (bangunan gedung, bangunan air, bangunan jalan dan jembatan) tidak lepas dalam kehidupan di masyarakat terlebih dunia usaha jasa konstruksi, maka mata pelajaran tersebut sangat berperan, (c) Pendekatan dan metode pembelajaran RAB Konstruksi: Dalam pelaksanaan pembelajaran guru dapat memilih dari beberapa pendekatan dan metode yang disesuaikan dengan kemampuan siswa, kekhasan dari pelajaran serta sarana dan kondisi peserta didik. Metode yang biasa dipakai adalah ceramah, tanya jawab, diskusi, penugasan, dan metode proyek (d) Media atau alat peraga, merupakan sumber belajar yang harus dikembangkan demi tercapainya hasil belajar yang optimal.

Dalam menyusun media RAB yang harus ada adalah (a) Gambar bestek (gambar kerja) atau gambar pelaksanaan, gambar bestek ini biasanya disajikan dalam bentuk 2 dimensi, namun dalam pembelajaran yang kami lakukan dalam bentuk file gambar 3 dimensi sehingga obyek gambar nampak sesuai dengan obyek asli (nyata), (b) Bestek atau uraian dan syarat-syarat pelaksanaan dimana fungsi dari bestek adalah untuk menjelaskan gambar agar dapat dibuat 
anggaran biaya dan memberi pengarahan dalam pelaksanaannya, maka gambar rencana harus dilengkapi dengan uraian dan syarat-syarat pelaksanaan (Muhammad dan Suratman, 1979: 5). Bestek juga dapat dinamakan Rencana Kerja dan Syarat (RKS) yang berisi tentang penjelasan atau aturan tertulis mengenai pelaksanaan pekerjaan yang meliputi penjelasan administrasi, penjelasan teknis dalam pelaksanaan pekerjaan, (c) Daftar harga satuan bahan bangunan dan upah pekerja yang dikeluarkan oleh pemerintah daerah setempat biasanya dengan keputusan bupati, (d) Prototype atau maket dari bangunan yang akan dikerjakan, model ini sangat efektif untuk memberikan gambaran yang nyata dari bangunan yang akan dikerjakan dalam ukuran diperkecil dengan skala tertentu, Seperangkat komputer untuk membuka file gambar dan media untuk menghitung Rencana Anggaran Biaya Bangunan dengan program Excel.

Sekaran dalam Sugiyono (2011: 65) mengemukakan bahwa, kerangka berpikir merupakan model konseptual tentang bagaimana teori berhubungan dengan berbagai faktor yang telah diidentifikasi sebagai masalah yang penting. Adapun kerangka berpikir atau kerangka teori dalam penelitian ini adalah (a) Pembelajaran merupakan proses interaksi peserta didik dengan pendidik dan sumber belajar yang terdapat pada suatu lingkungan belajar; (b) Model pembelajaran konstruktivistik adalah pembelajaran yang mengutamakan peserta didik secara aktif, membangun pembelajaran peserta didik sendiri secara mandiri dan menstransfer informasi kompleks; (c) Media pembelajaran adalah semua alat bantu atau benda yang digunakan untuk kegiatan belajar mengajar, dengan maksud menyampaikan pesan (informasi) pembelajaran dari sumber (guru maupun sumber lain) kepada penerima (dalam hal ini siswa atau warga belajar); (d) Motivasi belajar adalah daya penggerak psikis dalam diri seseorang untuk melakukan kegiatan belajar dan juga menambah keterampilan, pengetahuan. Motivasi mendorong dan mengarah minat belajar untuk mencapai tujuan; (e) Prestasi hasil belajar yang dinyatakan dalam bentuk nilai atau dalam bentuk skor, setelah siswa selesai mengikuti pelajaran.

\section{METODE}

Penelitian ini adalah penelitian tindakan kelas (classroom action research) yang termasuk penelitian deskriptif dalam bentuk penelitian kolaboratif karena peneliti bekerja sama dengan guru dengan dasar kompetensi yang sama sebagai mitra kolaborasi. Penelitian tindakan kelas ini bertujuan untuk memperbaiki dan meningkatkan praktik-praktik pembelajaran di kelas. Perbaikan dilakukan secara bertahap dan berkesinambungan sehingga pada akhirnya meningkatkan mutu hasil instruksional.

Rencana penelitian ini dengan dua siklus dan masing-masing siklus terdiri dari tiga pertemuan. Penelitian tindakan kelas di gambarkan sebagai proses yang dinamis dengan langkah yang berurutan dalam satu siklus atau pengulangan yang berhubungan dengan siklus berikutnya. Penelitian ini mengacu pada prinsip perbaikan pembelajaran yang berkesinambungan. Sebagai acuan menggunakan model Kemmis dan Taggart (1984). Kemmis dan Taggart (1984) menyatakan bahwa model penelitian tindakan adalah berbentuk spiral, dan pada hakekatnya berupa perangkat-perangkat atau urutan-urutan dengan satu perangkat terdiri dari komponen yaitu planning (perencanaan), action (tindakan), observation (pengamatan), dan reflection (refleksi), dari keempat komponen tersebut merupakan satu siklus. Langkah siklus berikutnya adalah perencanaan yang sudah direvisi, tindakan, pengamatan, dan refleksi. Tetapi sebelum melaksanakan masuk siklus I perlu dilakukan tindakan pendahuluan yang berupa identifikasi permasalahan. Siklus ini akan berlanjut secara berkesinambungan dan dihentikan apabila hasil sudah sesuai dengan kebutuhan dan dirasa sudah cukup. Model penelitian Kemmis dan Taggart tersebut dapat dijelaskan dalam Gambar 1 di bawah ini. 


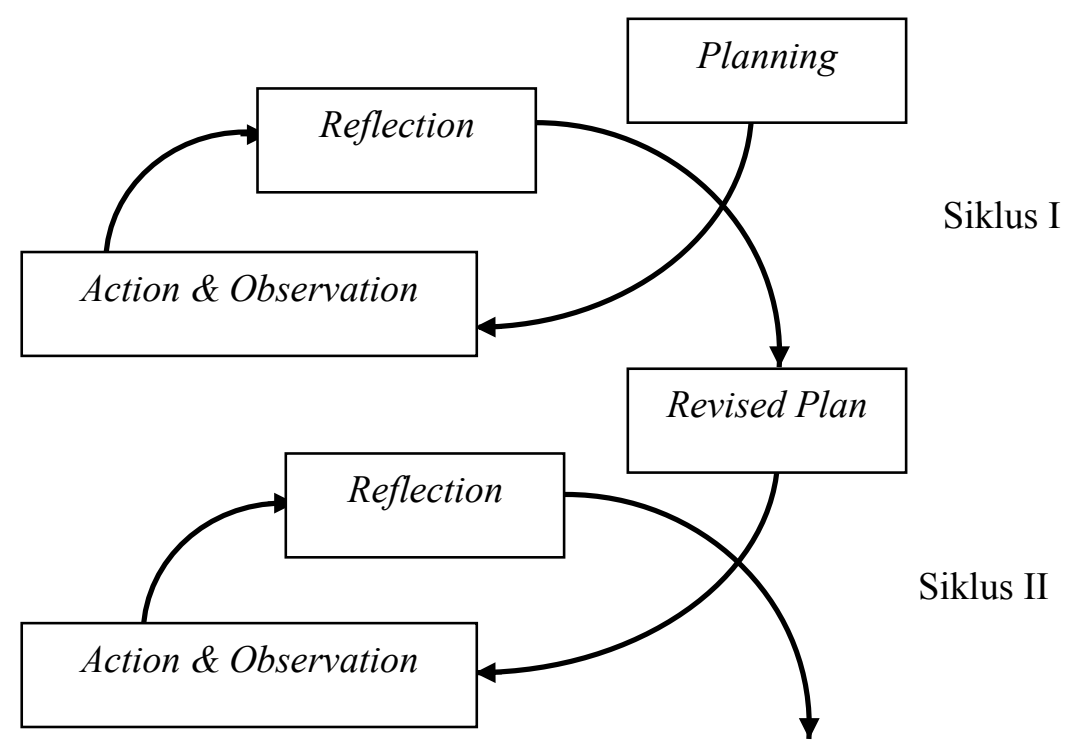

Gambar 1. Rancangan penelitian

(Sumber: Kemmis dan Taggart, 1984)

Penjelasan Gambar 1 di atas adalah sebagai berikut: (a) Perencanaan (planning), dilakukan sebelum melaksanakan tindakan antara lain; menyusun rumusan masalah, tujuan penelitian, menyusun rencana tindakan termasuk dalam tahapan ini yakni membuat instrumen penelitian dan perangkat pembelajaran dalam bentuk Rencana Pelaksanaan Pembelajaran (RPP); (b) Pelaksanaan dan Pengamatan (action and observation), pelaksanaan tindakan atau kegiatan pembelajaran di kelas atau di bengkel sesuai dengan rencana yang dibuat. Bersamaan dengan kegiatan ini dilakukan pengamatan oleh peneliti bersama dengan kolaborator terhadap jalannya tindakan disertai dengan pengamatan baik kepada guru atau peneliti maupuan siswa; (c) Refleksi (reflection), peneliti melihat, mengkaji, serta mempertimbangkan hasil dan gejala tindakan yang dilaksanakan berdasarkan lembar observasi yang sudah disiapkan dan diisi oleh pengamat dan teman kolaborasi; (d) Rancangan ulang yang sudah direvisi berdasarkan hasil refleksi dilakukan oleh pengamat sebagai dasar pelaksanaan tindakan pada siklus berikutnya.

Subyek tindakan adalah siswa kelas XII Teknik Konstruksi Kayu semester genap tahun pelajaran 2014/2015. Adapun pengamatan yang dilakukan selama tindakan penelitian ini meliputi: (a) Peningkatan motivasi siswa selama mengikuti kegiatan pembelajaran sesuai dengan sintaks dari model pembelajaran konstruktivistik; (b) Peningkatan prestasi belajar siswa pada mata pelajaran Menghitung RAB selama mengikuti pembelajaran dengan penerapan model konstruktivistik.

Waktu pelaksanaan penelitian adalah saat berlangsungnya penelitian dilakukan yaitu mulai bulan Januari sampai bulan Februari semester genap tahun pelajaran 2014/2015. Tempat penelitian di SMK Negeri 2 Pengasih, Daerah Istimewa Yogyakarta. Secara umum penelitian ini dilakukan melalui 5 (lima) tahap dari awal hingga penyusunan laporan, yaitu: (1) Perencanaan dan persiapan yang meliputi observasi di sekolah, penetapan materi pokok, menentukan indikator dan materi pembelajaran RAB bangunan, serta penetapan alokasi pelaksanaan dan juga penyusunan proposal; (2) Pelaksanaan tindakan yang meliputi seluruh proses kegiatan pembelajaran melalui model pembelajaran konstruktivistik dengan media file gambar 3 dimensi dengan skenario kegiatan pendahuluan, kegiatan inti (eksplorasi, elaborasi 
dan konfirmasi), dan kegiatan penutup. Bersamaan dengan tahapan pembelajaran tersebut guru menerapkan konsep model konstruktivistik yaitu dengan sintaks yaitu (a) apersepsi, (b) eksplorasi, (c) diskusi, dan (d) pengembangan dan aplikasi. Secara rinci skenario pembelajaran pada setiap siklus dijabarkan sebagai berikut (1) Kegiatan pendahuluan; (2) Kegiatan inti dengan sintak: (a) Eksplorasi, (b) Elaborasi, (c) Konfirmasi; (3) Kegiatan penutup. Pelaksanaan tindakan ini disajikan sesuai sintak model konstruktivistik.

(3) Observasi yang dilaksanakan oleh guru sebagai peneliti dan mitra kolaborasi untuk mengamati aktivitas dan motivasi siswa selama pembelajaran berlangsung, pengembangan materi, dan prestasi hasil belajar siswa, serta aktifitas guru. (4) Refleksi yang meliputi kegiatan identifikasi hasil observasi, analisis hasil observasi dan pengelolaan data dari hasil tindakan pembelajaran dan sekaligus menyusun rencana perbaikan pada siklus berikutnya. Refleksi ini menyangkut kepada guru sebagai peneliti dan siswa sebagai pembelajar. (5) Pada siklus II pembelajaran dilaksanakan dengan mengacu pada hasil refleksi pada akhir siklus I yang telah diperbaiki kekurangannya. Penyelesaian penyusunan laporan penelitian sesuai dengan hasil penelitian yang didapat.

Pengumpulan data dilakukan semenjak awal kegiatan penelitian dari siklus I sampai akhir siklus II oleh guru sebagai peneliti untuk mengamati kegiatan siswa selama mengikuti pembelajaran, dan oleh mitra kolaborasi mengamati kegiatan siswa dan guru selama melaksanakan proses pembelajaran. Semua yang dilakukan oleh guru dicatat oleh kolaborator mulai dari kegiatan awal, kegiatan inti, dan kegiatan akhir. Hasil pengamatan digunakan sebagai bahan refleksi terhadap proses pembelajaran.

Data motivasi belajar siswa digunakan angket pengukur motivasi model ARCS dari Keller (1983) pada empat kondisi motivasional yang terdiri dari perhatian (Attention), Relevansi (Relevance), Percaya diri (Confidence), dan Kepuasan (Satisfaction), dan pengamatan langsung terhadap aktivitas siswa selama mengikuti pembelajaran. Data prestasi hasil belajar menggunakan evaluasi atau tes tertulis dengan soal perhitungan RAB bangunan. Analisis data dilakukan secara kualitatif dan kuantitatif. Data peningkatan motivasi siswa dalam kegiatan belajar dilaporkan secara kuantitatif berdasarkan perolehan skor rata-rata motivasi pada tiap kriteria dari teori Keller. Peningkatan prestasi hasil belajar belajar dilaporkan dengan cara kuantitatif dengan rumus statistik sederhana. Analisis data hasil evaluasi dilakukan secara bersama-sama dengan mitra kolaborasi, kemudian dilakukan langkah interpretasi secara kualitatif berdasarkan teori yang dikemukakan. Sedangkan prestasi hasil belajar siswa dianalisa dengan dua kategori yaitu ketuntasan secara individu terhadap Kriteria Ketuntasan Minimal (KKM) dan secara klasikal berdasarkan rerata hasil evaluasi. Untuk menganalisis motivasi siswa dengan rumus:

$M_{\text {rata-rata }}=\frac{\text { Jumlah Skor Motivasi Belajar }}{\text { Jumlah Siswa } \times \text { Jumlah Item }}$

Sedangkan konversi taraf motivasi dijelaskan pada Tabel 1.

Tabel 1. Tabel konversi taraf motivasi

\begin{tabular}{cc}
\hline Interval & Kriteria \\
\hline $1,00<1,50$ & Tidak Baik \\
$1,50<2,50$ & Kurang Baik \\
$2,50<3,50$ & Cukup Baik \\
$3,50<4,50$ & Baik \\
$4,50<5,00$ & Sangat Baik \\
\hline
\end{tabular}

Analisis data hasil belajar siswa dengan rumus dari Suharsimi (2006).

$$
X_{\text {rata-rata }}=\frac{\sum X}{\sum N}
$$

Keterangan:

$\mathrm{X}$ rata-rata $=$ Nilai rata-rata klasikal

$\Sigma \mathrm{X} \quad=$ Jumlah nilai semua siswa

$\Sigma \mathrm{N} \quad=$ Jumlah siswa 
Untuk menganalisis daya serap siswa peneliti menggunakan rumus:

$$
D_{S S}=\frac{\sum X}{\sum N} x 100 \%
$$

Keterangan:

$$
\begin{array}{ll}
\text { Dss } & =\text { Daya serap siswa } \\
\Sigma \mathrm{X} & =\text { Jumlah nilai semua siswa } \\
\Sigma \mathrm{N} & \quad \text { Jumlah siswa }
\end{array}
$$

Ketuntasan belajar siswa dihitung dengan rumus:

$$
P=\frac{\sum T}{\sum N} x 100 \%
$$

Keterangan:

$$
\begin{array}{ll}
\mathrm{P} & =\text { Ketuntasan belajar siswa } \\
\Sigma \mathrm{T} & =\text { Jumlah siswa yang tuntas } \\
\Sigma \mathrm{N} & =\text { Jumlah siswa }
\end{array}
$$

Peningkatan prestasi hasil belajar dihitung menggunakan rumus:

$$
P=\frac{X_{2 \text { rerata }}-X_{1 \text { rerata }}}{\sum X_{1 \text { rerata }}} x 100 \%
$$

Keterangan :

$\mathrm{P} \quad=$ Persentase peningkatan hasil belajar

$\mathrm{X} 1=$ Rata-rata skor pada siklus II

$\mathrm{X} 2=$ Rata-rata skor pada siklus II

\section{HASIL DAN PEMBAHASAN}

Pada tahapan perencanaan, peneliti menyusun dokumen mutu guru sebagai perangkat pembelajaran termasuk Rencana Pelaksanaan Pembelajaran (RPP), masingmasing Kompetensi Dasar (KD), menyusun Lembar Kerja Siswa (LKS), soal evaluasi, dan perangkat pendukung lainnya. Pada tahapan pelaksanaan tindakan dan observasi, kegiatan pembelajaran siklus I terdiri dari tiga kali pertemuan. Jumlah siswa kelas III Teknik Konstruski Kayu tahun pelajaran 2014/2015 sebanyak 28 orang. Taraf motivasi belajar siswa diungkap dengan menggunakan angket motivasi model ARCS dari Keller dengan hasil yang dapat dilihat pada Tabel 2 di bawah ini.

Tabel 2. Data Rata-Rata Skor Motivasi Siswa pada Tindakan Siklus I

\begin{tabular}{clccl}
\hline No & \multicolumn{1}{c}{ Kondisi } & Jumlah skor & Rata-Rata & \multicolumn{1}{c}{ Kriteria } \\
\hline 1 & Perhatian (Attention) & 74,99 & 2,68 & Cukup Baik \\
2 & Relevansi (Relevansi) & 100,44 & 3,59 & Baik \\
3 & Percaya Diri (Confidence) & 81,27 & 2,90 & Cukup Baik \\
4 & Kepuasan (Statisfaction) & 84,46 & 3,02 & Cukup Baik \\
\hline
\end{tabular}

Berdasarkan Tabel 2 tersebut ternyata ada beberapa kondisi yang masih perlu mendapat perhatian karena belum memenuhi standar minimal, kekurangan dan kelemahan pada siklus I, dijadikan bahan kajian pada tahapan refleksi, revisi perbaikan untuk tindakan siklus II. Data hasil prestasi belajar siswa diperoleh melalui tes formatif 1 dengan rekapitulasi prestasi hasil belajar pada siklus I.

Tabel 3. Tabel Rekapitulasi Pretasi Hasil Belajar Siklus I

\begin{tabular}{clc}
\hline No & \multicolumn{1}{c}{ Uraian } & Hasil Tindakan Siklus I \\
\hline 1 & Rata-rata skor & $74,60 \%$ \\
2 & Daya serap & $74,60 \%$ \\
3 & Siswa yang tuntas & $21 \%$ \\
4 & Ketuntasan belajar & $57,14 \%$ \\
\hline
\end{tabular}

Tahapan refleksi bersama mitra kolaborasi diperoleh hasil bahwa: (a) Motivasi belajar siswa relatif masih rendah, (b) Siswa masih mengalami kesulitan dalam membaca gambar kerja atau gambar obyek, (c) Siswa masih mengalami kesulitan dalam aplikasi perhitungan. Pada revisi perencanaan, perbaikan rancangan dan perbaikan pembelajaran pada siklus II, 
dititikberatkan pada: (a) Kegiatan pendahuluan lebih ditekankan pada penyampaian tujuan pembelajaran secara rinci, pemberian motivasi kepada siswa lebih dioptimalkan, dan apersepsi penekanan pada penerapan pembelajaran dalam kehidupan sehari-hari di masyarakat, (b) Penekanan kejelian membaca gambar kerja dengan mengaktifkan "On" layer komponen obyek yang dihitung dan mematikan "Off" layer komponen obyek yang belum dihitung, (c) Mengintensifkan pendampingan dalam perhitungan.
Tahapan perencanaan yaitu melakukan penyusunan perangkat pembelajaran berupa Rencana Pelaksanaan Pembelajaran (RPP) Lembar Kerja Siswa (LKS), dan soal evaluasi atau tes formatif siklus II berdasar rekomendasi refleksi pada siklus I. Tahapan Pelaksanaan dan observasi pada siklus II dilakukan empat kali. Pengamatan dilakukan oleh mitra kolaborasi dan hasil observasi motivasi siswa pada siklus II diungkap dengan angket pengukur motivasi model ARCS dengan hasil seperti Tabel 4.

Tabel 4. Data Rata-Rata Skor Motivasi Siswa pada Tindakan Siklus II

\begin{tabular}{clccl}
\hline No & \multicolumn{1}{c}{ Kondisi } & Jumlah Skor & Rata-Rata & \multicolumn{1}{c}{ Kriteria } \\
\hline 1 & Perhatian (Attention) & 103,40 & 3,69 & Baik \\
2 & Relevansi (Relevansi) & 129,45 & 4,62 & Sangat Baik \\
3 & Percaya Diri (Confidence) & 103,82 & 3,71 & Baik \\
4 & Kepuasan (Statisfaction) & 102,81 & 3,67 & Baik \\
\hline
\end{tabular}

Dapat dilihat pada siklus II ini motivasi pada masing-masing kondisi telah mengalami peningkatan yang signifikan. Sedangkan data hasil evaluasi tes formatif II dijelaskan pada Tabel 5 sebagai berikut.

Tabel 5. Rekapitulasi Prestasi Hasil Belajar Siklus II

\begin{tabular}{|c|c|c|}
\hline No & Uraian & Hasil Tindakan Siklus II \\
\hline 1 & Rata-rata skor & $80,09 \%$ \\
\hline 2 & Daya serap & $80,09 \%$ \\
\hline 3 & Siswa yang tuntas & $28 \%$ \\
\hline 4 & Ketuntasan belajar & $100 \%$ \\
\hline
\end{tabular}

Pada tahapan refleksi peneliti mencermati kembali pelaksanaan pembelajaran maupun aspek-aspek yang masih kurang, sehingga hasilnya dijadikan rekomendasi perbaikan pelaksanaan pembelajaran mendatang. Secara umum penelitian telah berhasil dengan baik. Berdasarkan data-data hasil penelitian tentang penerapan model konstruktivistik dengan media file gambar 3 dimensi dalam meningkatkan motivasi dan prestasi belajar Rencana Anggaran Biaya pada siswa kelas III Teknik Konstruksi Kayu di SMK N 2 Pengasih tahun 2014/2015 dapat diinterpretasikan bahwa (1) Penerapan model konstruktivistik berhasil meningkatkan motivasi belajar siswa, hal ini dapat dilihat dari analisa data motivasi siswa yang ditinjau dengan 4 kondisi motivasional menurut teori Keller yaitu secara klasikal pada siklus I ratarata untuk kondisi (a) perhatian (attention) 2,68\%, (b) relevansi (relevance) 3,59\%, (c) percaya diri (confidence) 2,90\%, dan (d) kepuasan (satisfaction) 3,02\%. Sedangkan pada akhir tindakan atau pembelajaran siklus II diperoleh data motivasi belajar siswa dengan kondisi berikut: (a) perhatian (attention) 3,69\%, (b) relevansi (relevance) 4,62\%, (c) percaya diri (confidence) 3,71\%, serta (d) kepuasan (satisfaction) 3,67\%. Dalam bentuk tabel maka dapat dilihat motivasi belajar dari akhir siklus I dan akhir siklus II penelitian ini pada Tabel 6 . 
Tabel 6. Rekapitulasi Taraf Motivasi Siklus I dan Siklus II

\begin{tabular}{clccccc}
\hline \multirow{2}{*}{ No } & \multicolumn{1}{c}{ Kondisi } & \multicolumn{2}{c}{ Siklus I } & \multicolumn{2}{c}{ Siklus II } & \multirow{2}{*}{ Peningkatan } \\
\hline \multirow{2}{*}{1} & $\begin{array}{l}\text { Perhatian } \\
\text { (Attention) }\end{array}$ & 2,68 & Cukup Baik & 3,69 & Baik & $37,69 \%$ \\
2 & $\begin{array}{l}\text { Relevansi } \\
\text { (Relevansi) }\end{array}$ & 3,59 & Baik & 4,62 & Sangat Baik & $28,69 \%$ \\
3 & $\begin{array}{l}\text { Percaya Diri } \\
\text { (Confidence) }\end{array}$ & 2,90 & Cukup Baik & 3,71 & Baik & $27,93 \%$ \\
4 & $\begin{array}{l}\text { Kepuasan } \\
\text { (Statisfaction) }\end{array}$ & 3,02 & Cukup Baik & 3,67 & Baik & $21,52 \%$ \\
\hline
\end{tabular}

(2) Penerapan model konstruktivistik dapat meningkatkan prestasi hasil belajar siswa, dengan data siklus I; pencapaian skor rata-rata secara klasikal dari 28 siswa 74,60; daya serap $74,60 \%$; dan ketuntasan belajar $57,14 \%$ Kegiatan pembelajaran siklus II diperoleh data pencapaian skor rata-rata secara klasikal dari 28 siswa adalah 80,09; daya serap 80,09 \%; dan ketuntasan belajar $100 \%$ semua siswa tuntas. Dari data tersebut dapat dilihat peningkatan prestasi hasil belajar pada siklus I dan siklus II yaitu (a) peningkatan skor rata-rata 7,36\%, (b) peningkatan pencapaian daya serap $7,36 \%$, dan (c) peningkatan ketuntasan belajar 75,01\%, Data tersebut secara rinci dapat dilihat dalam Tabel 11.

Tabel 11. Prestasi Hasil Belajar Siklus I dan Siklus II

\begin{tabular}{clccc}
\hline No & \multicolumn{1}{c}{ Uraian } & Siklus I & Siklus II & Peningkatan \\
\hline 1 & Skor rata-rata & 74,60 & 80,09 & $7,36 \%$ \\
2 & Daya serap & $74,60 \%$ & $80,09 \%$ & $7,36 \%$ \\
3 & Ketuntasan belajar & $57,14 \%$ & $100,00 \%$ & $75,01 \%$ \\
\hline
\end{tabular}

Berdasarkan data, tabel, dan grafik prestasi hasil belajar diatas dapat diinterpretasikan bahwa semua kekurangan dan kelemahan yang terjadi pada pelaksanaan tindakan atau pembelajaran siklus I telah teratasi dengan peningkatan prestasi belajar siswa. Peningkatan prestasi akan berdampak positif terhadap peningkatan mutu dan kualitas pembelajaran SMK Negeri 2 Pengasih Kulon Progo.

\section{SIMPULAN}

Berdasarkan hasil penelitian dapat disimpulkan bahwa (1) Penerapan model konstruktivistik dapat meningkatkan motivasi belajar pada mata pelajaran Rencana Anggaran Biaya bangunan siswa kelas III Teknik Konstruksi Kayu SMK Negeri 2 Pengasih Kulonprogo tahun pelajaran 2014/2015. Pada motivasi belajar siklus I, tiga indikator berada pada interval (2,50 sampai dengan 3,50) dengan kriteria cukup baik, dan satu indikator pada interval (3,50 sampai dengan 4,50) dengan kriteria baik. Pada siklus II pencapaian motivasi belajar siswa tiga indikator pada interval $(3,50$ sampai dengan 4,50) dengan kriteria baik, satu indikator berada pada interval (4,50 sampai dengan 5,00) dengan kriteria sangat baik, (2) Penerapan model konstruktivistik dapat meningkatkan prestasi hasil belajar pada mata pelajaran Rencana Anggaran Biaya bangunan siswa kelas III Teknik Konstruksi Kayu SMK Negeri 2 Pengasih Kulon Progo tahun pelajaran 2014/2015. Data siklus I, skor rata-rata 74,60; daya serap 74,60\%; dan ketuntasan belajar 57,14\%. Pada akhir siklus II, skor rata-rata 80,09; daya serap 80,09\%; dan ketuntasan belajar $100 \%$. Berdasarkan data tersebut maka peningkatan prestasi hasil belajar siswa yaitu skor meningkat $7,36 \%$; daya serap meningkat $7,36 \%$; dan ketuntasan belajar meningkat $75,01 \%$. 


\section{DAFTAR RUJUKAN}

Akhmad Sudrajat. 2008. Pengertian, Fungsi, dan Jenis Media Pembelajaran. Diambil dari https://akhmadsudrajat.wordpress. com/2008/01/12/konsep-mediapembelaja ran / pada 21 Desember 2014

Arief S Sadiman, R. Rahardjo, Anung Haryono, Rahardjito. 2008. Media Pendidikan. Jakarta: Raja Grafindo Persada

Aronson E., Stephen C., Sikes J., Blaney N. and Snapp M.. 1978. The Jigsaw Classroom. Beverly Hills: Sage Publications

Daryanto. 2011. Penelitian Tindakan Kelas dan Penelitian Tindakan Sekolah. Yogyakarta: Gava Media

Degeng, N. S. 2001. Media Pembelajaran. Dalam kumpulan makalah Pekerti (Pengembangan Keterampilan Instruktur) untuk Quantum Teaching. Tidak diterbitkan

Dhani Azzuri. 2014. Model Pembelajaran Konstruktivistik. Diambil dari https:// dhanz3rd.wordpress.com/2014/02/14/file -systemdiwindows-dan-linux/ pada 21 Desember 2014

Endang Mulyatiningsih. 2011. Riset Terapan Bidang Pendidikan \& Teknik. Yogyakarta: UNY Press

John Latuheru. 1988. Media Pembelajaran: Dalam Proses Belajar Mengajar Masa Kini. Jakarta: P2LPTK

Keller, J. M. 1983. Motivation Design of Instruction, in Instructional-Design Theories and Models: An Overview of Their Current Status. Hillsdale: Lawrence Erlbaum Associates Publishers

Kemmis, Stephen and Taggart, Robon Mc. 1984. The Action Research Planner. Victoria: Deakin University
Mohammad Nur. 2001. Pemotivasian Siswa untuk Belajar. Surabaya: University Press

Muhammad Sukoadji dan Suratman. 1979. Pengetahuan Industri dan Rencana Anggaran I. Jakarta: Direktorat Pendidikan Menengah dan Kejuruan

Pusat Bahasa Depdiknas. 1996. Kamus Besar Bahasa Indonesia. Jakarta: Balai Pustaka

Schramm, Wilbur. 1977. Big Media, Little Media, Tools, and Technologies for Instruction. London: Sage Publications

Soetomo. 1993. Pembelajaran Menyenangkan untuk Anak-anak Autis. Jakarta: Bumi Aksara

Sugiyono. 2011. Metode Penelitian Administrasi. Bandung: Alfabeta

Suharsimi Arikunto. 2006. Prosedur Penelitian Suatu Pendekatan Praktik. Jakarta: Rineka Cipta

Syaiful Bachri Djamarah. 2002. Psikologi Belajar. Jakarta: Rineka Cipta

Tukiran Taniredja, Irma Pujiati, dan Nyata. 2011. Penelitian Tindakan Kelas Untuk Pengembangan Profesi Guru. Bandung: Alfabeta

Undang-Undang Republik Indonesia Nomor 20 Tahun 2003 tentang Sistem Pendidikan Nasional. Jakarta: Lembaran Negara Republik Indonesia Tahun 2003 Nomor 4301

Uzer Usman. 2000. Menjadi Guru Profesional. Bandung: PT Remaja Rosdakarya

Zainal Aqib. 2006. Penelitian Tindakan Kelas Untuk Guru. Bandung: Yrama Widya 